\title{
Identification of Road Condition Survey Results on the Making of Map of Palembang City Road Network Based on GIS
}

\author{
Norca Praditya ${ }^{1}$, Indrayani Indrayani ${ }^{1, *}$, Andi Herius ${ }^{1}$, Kosim Kosim $^{1}$, \\ Tata Peryoga ${ }^{2}$, Mendro Anggoro ${ }^{2}$ \\ ${ }^{1}$ Civil Engineering Department, Politeknik Negeri Sriwijaya, Palembang Indonesia \\ ${ }^{2}$ IDN Western Australia, Perth \\ ${ }^{*}$ Corresponding author. Email: iin_indrayani@polsri.ac.id
}

\begin{abstract}
The road network that is spread throughout the Palembang city certainly has different conditions depending on the use of the road, on some roads that are often flooded or passed by vehicles with excess loads become damaged more quickly before the achievement of the service life of the road, this road damage will certainly cause inconvenience in road use, for this reason road maintenance is needed so that damaged roads can be repaired immediately. The method that can be used in assessing road conditions is the SDI (Surface Distress Index) method, then the results of this assessment can be used as attributes in a road network map, namely by entering these values into a GIS-based thematic map, so that information on road conditions can be easily accessed. easily obtained when the user accesses the location of the road on the map of the existing road network. The initial step taken is to conduct a road condition survey on all roads under the authority of the Palembang City government based on the Palembang Mayor's Decree in 2011. The results of the data analysis show that in general the road conditions in Palembang City are in good condition, this can be seen from the results of the analysis of the length of the road. in good condition of 505,670 km of the total road length of 681.75 $\mathrm{km}$ or $74.17 \%$.
\end{abstract}

Keywords: Identification, Value of Road Conditions, Maps, GIS.

\section{INTRODUCTION}

Palembang is the capital city of South Sumatra Province, located between $2^{\circ} 52^{\prime} 3^{\circ} 5^{\prime}$ South Latitude and $104^{\circ} 37^{\prime} 104^{\circ} 52^{\prime}$ East Longitude and is directly adjacent to Banyuasin Regency in the North, East and West, while in the south it is bordered by Muara Enim Regency and Ogan Ilir Regency. Administratively Palembang has 18 sub-district with 107 villages, with an area of $400.61 \mathrm{~km}^{2}$ [2] [3].

Economic growth in the city of Palembang continues to increase along with higher population growth, this is certainly related to the existence of existing road infrastructure. The higher the quality of the existing roads, the easier it will be for every access to activities carried out. The road network that is spread throughout the city of Palembang of course

has different conditions depending on the use of the road, on some roads that are often flooded or traversed by vehicles with excessive loads, or unstable soil conditions will become damaged more quickly before reaching age. road service, this road damage will certainly cause inconvenience in road use $[4][5][7][8][11]$.

Good road infrastructure in addition to providing comfort for road users, can also support increased economic growth, for this reason it is necessary to carry out routine road maintenance activities, especially on roads that are no longer able to support the comfort of road users. In order for road maintenance to be in accordance with the existing road conditions, it is necessary to assess the existing road conditions and then include it in a road network map, so that in one map the information needed for road maintenance has been integrated, including information about the type of road pavement and index. the road conditions [6][9][10]. Ease of access to information can be done through the use of GIS-based 
thematic maps that are equipped with the necessary supporting attributes, so that by accessing the thematic maps the information needed can be obtained easily [5][7][13].

From this background, it is necessary to identify road conditions with the aim of being able to be used as attributes in the preparation of a road network map in the Palembang city GIS-based. This road network map is expected to provide fast information on the existing road conditions, for example the coordinates of the location of the damaged road complete with information on the type of pavement and road conditions. This information will be needed when evaluating road conditions in Palembang City.

\section{METHODOLOGY}

\subsection{Location, tools, and materials}

Road condition survey was carried out on roads in Palembang City which are under the authority of the Palembang City Government as stated in the Palembang Mayor's Decree [3]. The tools used in the Road condition survey include: survey form issued by the Ministry of Public Works The Directorate General of Highways, which is used to record the damage that occurs on the road, length measuring device (meter) and roller meter to measure physical damage and roads, mobile phones with geotagging applications to record the coordinates of the position of road damage, and GPS navigation (Garmin Etrex 10) which is used to track the roads that have been inspected which will later be used as the basis for making the thematic maps of the road network.

\subsection{Road Condition Survey}

Making a road network map of the city of Palembang starts from a preliminary survey to obtain information on the function of each object to be studied. Furthermore, a road condition survey was conducted to obtain data on the existing road conditions. A survey of road conditions was carried out by a surveyor team consisting of 4 people with a background in Civil Engineering.

The road data needed to obtain road conditions includes 2 main elements, namely: (1) road pavement data, consisting of road pavement surface data, cracks in the road, and other damage data such as the number of holes, size of holes, ruts, and edge damage.; to (2) shoulder, side channel, consisting of shoulder condition, shoulder surface, side channel condition, slope damage, and pavement.

\subsection{Data Analysis}

Analysis of the value of road conditions is calculated based on the parameters of the SDI (Surface Distress Index) value with the help of the Ms. Excel. The calculation of road surface conditions can be seen in Figure 1 [3]

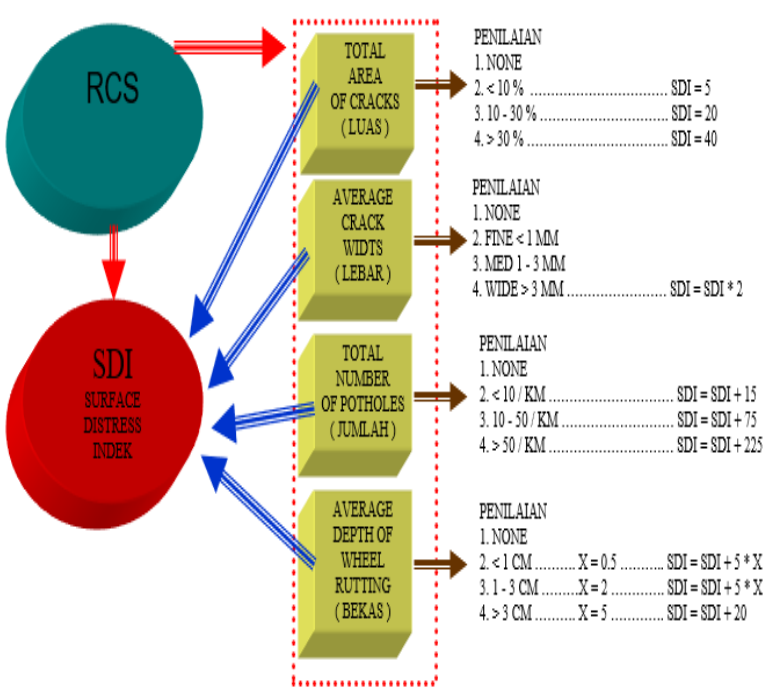

Figure 1. Calculation of Road Surface Conditions with the SDI Method

While the value of road surface conditions using the SDI method can be seen in Table 1 [3].

Table 1. Road Surface Condition with SDI Method Road Surface Condition SDI Value

\begin{tabular}{lc} 
Good & $<50$ \\
Moderate & $50-100$ \\
Slightly Damaged & $100-150$ \\
Severely Damaged & $>150$ \\
\hline
\end{tabular}

Furthermore, from the results of the analysis of road conditions, it is entered into the road network map attributes so that each road segment has condition information from existing path

\section{RESULT AND DISCUSSION}

\subsection{Road Condition Inspection Results}

The results of road condition inspections in Palembang City consist of 4 conditions as shown in Figure 2, namely the condition of the starting point for road inspections on Karya Jaya Street Sta $0+000-0+680$.

In Figure 2 it can be seen that road inspections are carried out within a distance of $200 \mathrm{~m}$ and each 
inspection result is entered in the inspection form to be reported.

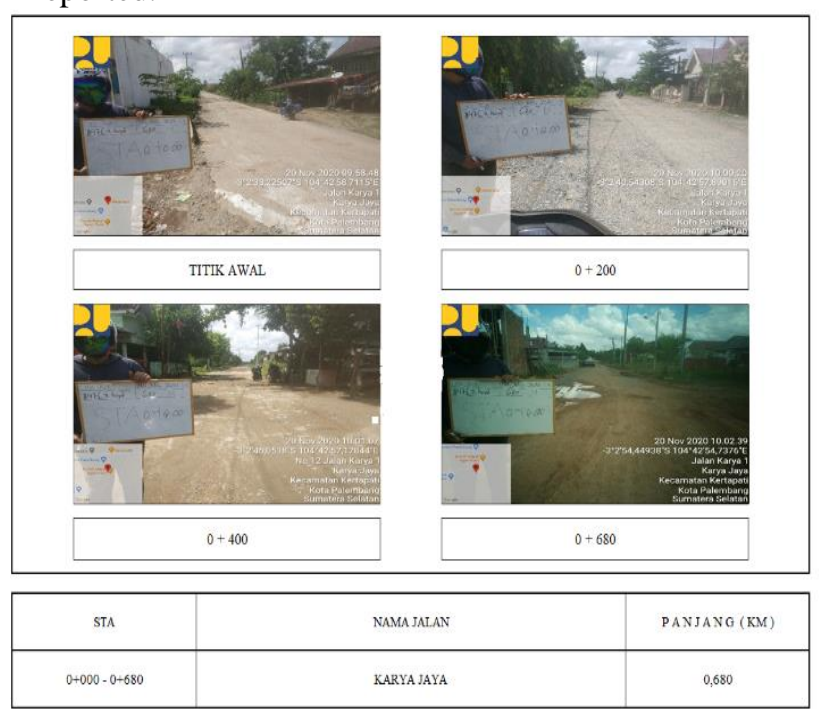

Figure 2 Road Condition Inspection on Karya Jaya Street

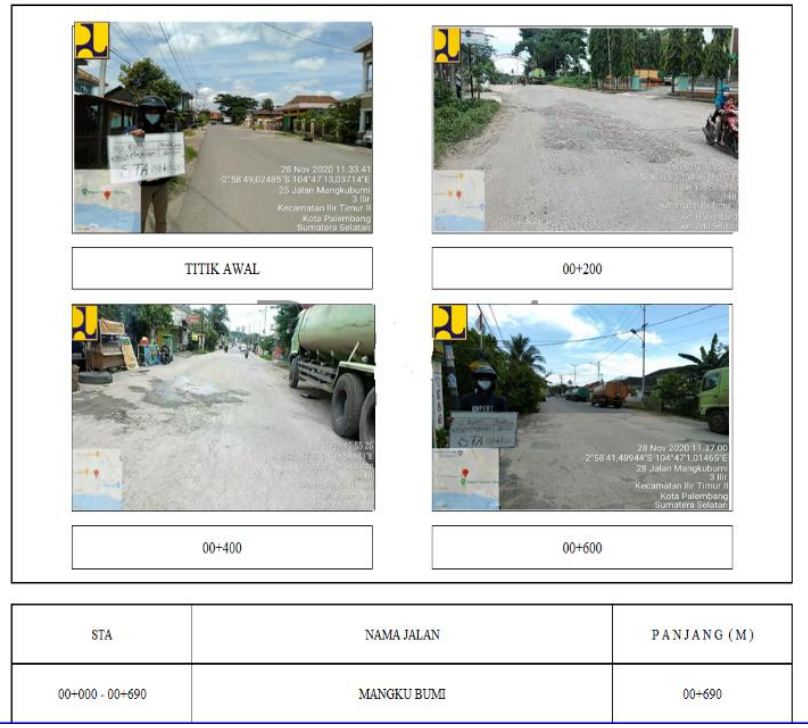

Figure 3. Road Condition Inspection on Mangku Negara

Street

\subsection{Results of Road Condition Assessment using the SDI Method}

From the results of the subsequent inspection, an assessment was carried out using the SDI method. From the analysis of road condition assessment, there are 1204 roads in the city of Palembang which are included in the area of authority of the Palembang City Government based on the Decree of the Mayor of Palembang [3]. The road consists of arterial roads, collector roads, local roads, and other roads including environmental roads which are spread across 18 subdistricts in Palembang City with a total road length of $681.75 \mathrm{~km}$. While the identification of the pavement can be seen in Table 2 and the identification of the value of road conditions can be seen in Table 3 .
Table 2. Identification of the pavement

\begin{tabular}{llc}
$\begin{array}{l}\text { Pavement } \\
\text { Materials }\end{array}$ & Condition & $\begin{array}{c}\text { Total Road } \\
\text { (Segment) }\end{array}$ \\
\hline & Asphalt Pavement & 782 \\
& Concrete Pavement & 404 \\
& Gravel Pavement & 2 \\
& Soil Pavement & 16 \\
\hline & Total Roads & 1204 \\
\hline
\end{tabular}

Table 3. Identification of Road Conditions in Palembang City

\begin{tabular}{llc}
$\begin{array}{l}\text { Road } \\
\text { Condition } \\
\text { Description }\end{array}$ & Condition & $\begin{array}{c}\text { Length } \\
\text { Conditions } \\
(\mathrm{km})\end{array}$ \\
& Good & 505.670 \\
& Moderate & 58.630 \\
& Slightly Damaged & 84.350 \\
& Severely Damaged & 33.100 \\
\hline & Total Road Length & 681.750 \\
\hline
\end{tabular}

From Table 2, it can be seen that the type of pavement in the city of Palembang mostly uses asphalt pavement, which is 782 roads from a total of 1204 roads. Meanwhile, from Table 3, it can be seen that the road conditions in the city of Palembang show that most of the roads are in good condition, which is $505,670 \mathrm{~km}$ long.

\subsection{Thematic Map of the Palembang City Road Network The}

Steps taken in creating a geodatabase, namely [1]:

1. Transferring the tracking of roads in the city of Palembang using GPS navigation (*.gpx format) with $0-7 \mathrm{~m}$ correction to the Garmin application.

2. Basecamp. The results of road tracking can be seen in Figure 4.

3. Maps that have been processed in the Garmin Basecamp application (*.gpx) are exported to the GIS (Geographic Information System) application. The road GIS map of the city of Palembang can be seen in Figure 5.

4. After making the GIS map, then the author fills in the road data that will be displayed on the GIS Map of the City of Palembang. The display of filling in road data on a GIS map can be seen in Figure 6. 


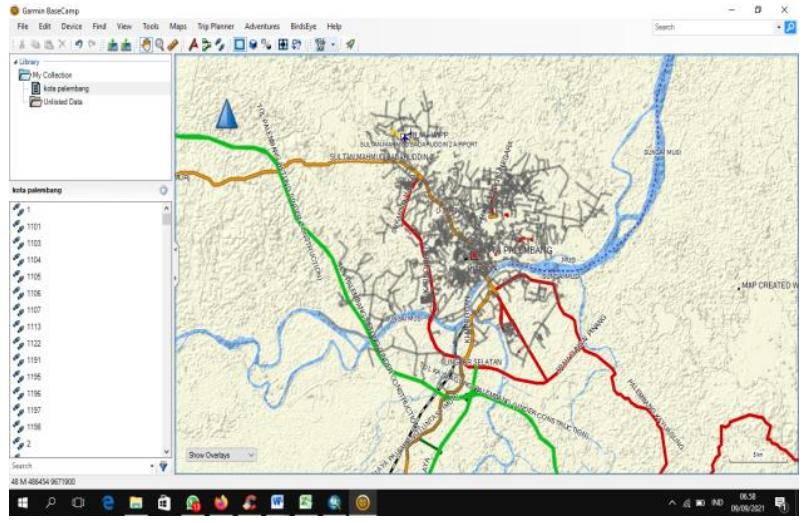

Figure 4. Palembang City Road Tracking According to the Palembang Mayor's Decree

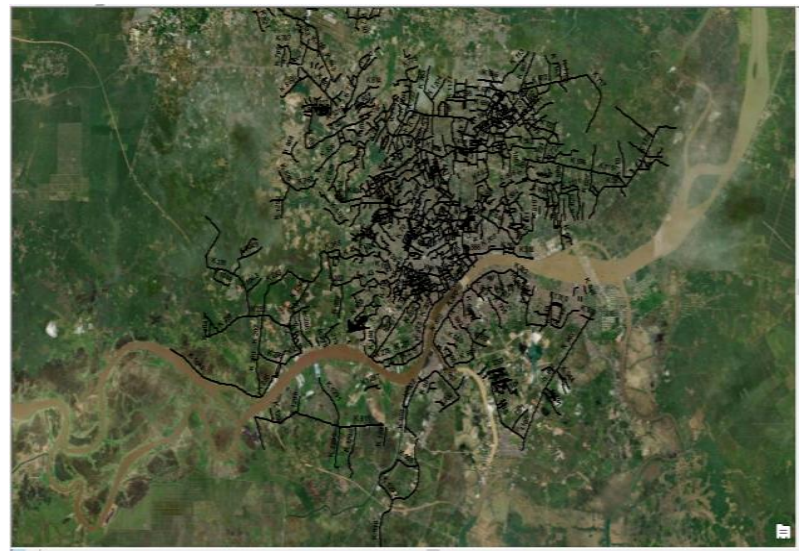

Figure 5. Map of the Road Network of the City of Palembang in accordance with Palembang Mayor's Decree.

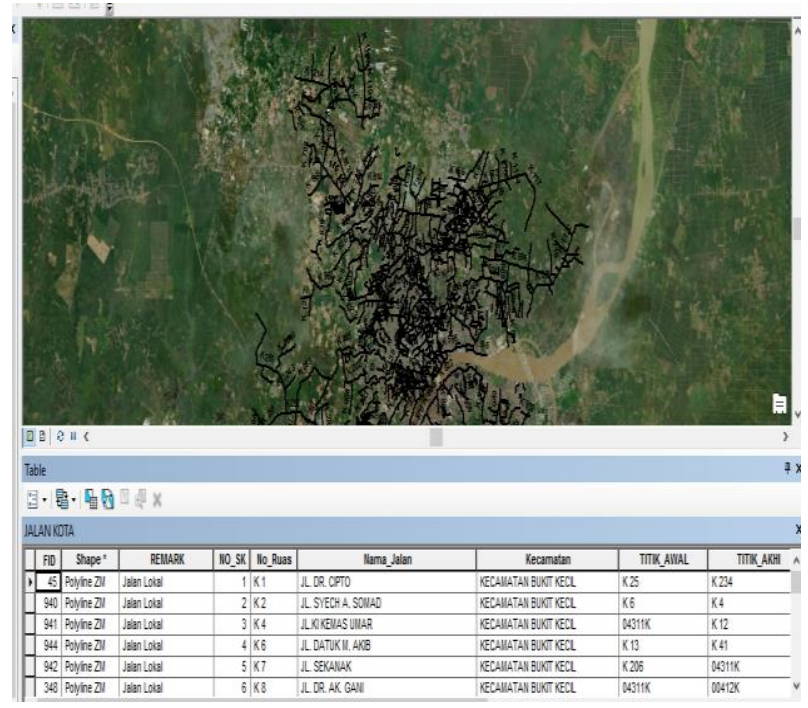

Figure 6. Map of the Palembang City Road Network and its Attributes

\subsection{Discussion}

Map of the Palembang city road network that has been equipped with complete attributes ranging from road width, road length, type of pavement, and road conditions will certainly make it easier for users to obtain information on existing road conditions. Users in this case the government can use this road map as a guide in planning the maintenance and development of the existing road network in the city of Palembang.

\section{CONCLUSIONS}

From the results of the discussion, it can be concluded that in general the road pavements in the city of Palembang use asphalt pavement as many as 782 roads out of a total of 1204 roads, while the road conditions in the city of Palembang are in good condition, this can be seen from the results of the analysis which show that $505,670 \mathrm{~km}$ of the total road length of $681.75 \mathrm{~km}$ or $74.17 \%$ road conditions in Palembang City are good.

\section{ACKNOWLEDGMENTS}

Thanks to Polytechnic State of Sriwijaya for funding the assignment research.

\section{REFERENCES}

[1] B. P. P. D. (BAPPEDA), 2013. Tentang Peta dan Pemetaan. [Online]. Available: https://bappeda. grobogan.go.id/berita/serba-serbi/112-tentang-petadan-pemetaan.

[2] BPS Kota Palembang, 2020. Palembang dalam Angka.

[3] Direktorat Jenderal Bina Marga, 2011. Manual Konstruksi dan Bangunan, No. 001-01/M/BM/ 2011, Survei Kondisi Jalan untuk Pemeliharaan Rutin. Kementerian Pekerjaan Umum, Direktorat Jenderal Bina Marga.

[4] Yuniar, D., Fatihin, H., 2016. Identifikasi Kerusakan Jalan dan Penanganan Perbaikan pada Jalan Tambang. Jurnal Sains dan Terapan Politeknik Hasnur.

[5] Hasan, A., Indrayani, Prabudi, D., 2019. "Aplikasi Teknologi Remote Sensing Terhadap Sebaran Jaringan Jalan di Kota Palembang”. Jurnal Rekayasa Sipil, Vol. 15, No. 2.

[6] Giannastiar, M., 2016. Sistem Pelaporan Kerusakan Jalan pada Bina Marga Makassar Berbasis WEB dan Mobile. Skripsi Mahasiswa, Universitas Islam Negeri Alauddin Makassar.

[7] Indrayani, Hasan, A., 2018. Analisis Spasial Aspek Topografi Menggunakan Citra Demsrtm Sebagai Dasar Perencanaan Jalan. Pilar Jurnal, Vol 13, No. 2.

[8] Praditya, N., Indrayani, 2020. Analisis Tebal Perkerasan Jalan Lingkar Perkantoran Gerbang 1 Gerbang 2 Kabupaten Banyuasin Menggunakan Metode MDP 2013. Jurnal Fropil, Vol 8 No. 2.

[9] Praditya, 2017. Pengembangan Program Penanganan Jalan Menggunakan GIS Pada Jalan Nasional di Provinsi Sumatera Selatan. UNIID. Jakarta. 
[10] Prabudi, D., Indrayani, 2020. Identifikasi Jenis dan Berat Kendaraan Terhadap Tata Guna Lahan Sebagai Dasar Perencanaan Jalan. Pilar Jurnal, Vol. 15 No. 01.

[11] Yudaningrum,F., Ikhwanudin, 2017. Identifikasi Jenis Kerusakan Jalan (Studi Kasus Ruas Jalan
Kendungmundu-Meteseh). Teknika, Vol. XII, No. 2, pp 16-23.

[12] Indrayani, 2021. Trase Jalan pada Daerah Rawa Berbasis Spasial. Pustaka Aksara, Surabaya. 